\title{
Studies on Genetic Variability, Heritability, Genetic Advance, Correlation and Path Analysis for Grain Yield and its Contributing Traits in Indigenous Wheat (Triticum aestivum L.)
}

\author{
Suryabhushan Kumar ${ }^{1}$, Brijesh Singh ${ }^{1}$, S.P. Verma ${ }^{1 *}$, V.N. Pathak ${ }^{1}$, \\ Chaman Jee $^{1}$ and J.P. Singh ${ }^{2}$ \\ ${ }^{1}$ Department of Genetics \& Plant Breeding, SMM Town Post Graduate College, \\ Ballia, Uttar Pradesh, India \\ ${ }^{2}$ Department of Plant Pathology, SMM Town Post Graduate College, Ballia, \\ Uttar Pradesh, India \\ *Corresponding author
}

\section{A B S T R A C T}

The present investigation was carried out with twenty (with two checks) indigenous genotypes of wheat to study the variability, heritability and genetic advance. The field experiment was conducted

Keywords

Wheat, (Triticum aestivum $\mathrm{L})$, variability, $h^{2}$ Correlation and path analysis

Article Info

Accepted:

12 July 2019

Available Online:

10 August 2019 under timely sown condition during Rabi 2017-18 in randomized block design with three replication at Nidhariya Agriculture farm S.M.M. TOWN P.G. College Ballia, U.P. The data were recorded on twelve characters viz. days to 50\% flowering, tillers per plant, flag leaf area, plant height, ear length, days to maturity, biological yield, ear weight, number of grains per ear, harvest index, test weight and grain yield per plant. Analysis of variance revealed that the treatments differed significant for all the characters under study except tillers per plant, ear length per plant and ear weight per plant which indicated the material to be of different genetic constitution. The highest values for GCV \& PCV were recorded for the character biological yield per plant and grain yield per plant. High heritability along with high genetic advance was obtained for plant height, flag leaf area, biological yield and test weight indicating that traits were under additive gene control and selection for genetic improvement for these traits would be effective. The data showed that the grain yield had significant and positive association with days to $50 \%$ flowering (0.423), tillers per plant $(0.3039)$, flag leaf area (0.3252), plant height $(0.3450)$, ear length $(0.3891)$, biological yield per plant $(0.6292)$, ear weight (0.6420), harvest index $(0.40040$ and test weight (0.5527). Path coefficient analysis revealed that biological yield per plant $(0.5356)$ had the highest positive direct effect on grain yield per plant followed by harvest index (0.3289). The results revealed that these traits may serve as effective selection attribute during selection in breeding program for yield improvement in wheat.

\section{Introduction}

Wheat (Triticum aestivum L. $2 \mathrm{n}=42$ ), a selfpollinated crop of the Gramineae family and genus Triticum, is the world's largest famous energy rich cereal crop. Wheat is the second most important cereal staple food crop consumed nearly $35 \%$ of world population and provides $20 \%$ food calories. India is the second largest wheat growing country of the world after the China. The world acreage under wheat crop during 2017 - 2018 was 229.67 million hectare with production of 759.75 million tones with an average yield of 
33.08 quintal / hectare. In India, the total area for wheat crop during 2017 - 2018 was 31.68 million hectare with production of 97.11 million tones and average productivity was 30.66 quintal / hectare. Uttar Pradesh ranked first with an area of 9878 hectare with the production of 30 million tones with average productivity of 30.76 quintal / hectare. The productivity of wheat in other state is comparatively lower than that of Punjab and Haryana. In Ballia district during 2017 - 2018 total wheat cultivated area 137.665 thousand hectare and production 542.431 thousand metric ton and productivity $39.40 \mathrm{q} / \mathrm{ha}$. Grain yield is a complex trait and highly influenced by the action and interactions of various component characters (Grafius, 1960). Correlation coefficient measures the degree of mutual association between two variables without employing any cause and effect relationship. All possible correlation coefficient among 12 characters were calculated at genotypic and phenotypic level following the procedure of Searle (1961) Path coefficient is simply a standardized partial regression coefficient and such measure the direct influence on variable upon another and permitted the correlation coefficient in to component of direct and indirect effects (Wright 1921). The concept of path analysis was later on elaborated by Dewey and $\mathrm{Lu}$ (1959).

\section{Materials and Methods}

The experiment of present investigation was conducted to evaluate the twenty wheat germplasm lines including two checks (namelyPBW-343 and PBW-502) in Randomized Block Design with three replication at Agricultural Research Farm, Nidharia, S.M.M. Town Post Graduate College, Ballia (U.P.). These genotypes exhibited wide spectrum of variation for various agronomical and morphological characters. Each genotype was sown in 3 meters length, row to row spaced $30 \mathrm{~cm}$ and intra row spacing of $5 \mathrm{~cm}$ all recommended cultural practices and plant protection measures were applied to raise to healthy crop.

The data were recorded on twelve quantitative traits namely days to $50 \%$ flowering, flag leaf area $\left(\mathrm{cm}^{2}\right)$, plant height $(\mathrm{cm})$, ear length $(\mathrm{cm})$, tillers per plant, days to maturity, ear weight per plant $(\mathrm{g})$, number of grain per ear, biological yield (g), harvest index (\%), test weight (g) and grain yield/plant (g). From five randomly selected plants and days to 50\% flowering and days to maturity were recorded on plot basis and all data were analyzed by standard statistical method.

\section{Results and Discussion}

The analysis of variance revealed significant differences among the treatment for all the characters except tillers per plant, ear length and ear weight. Therefore these characters are not considerable for any further breeding programmes (Table 1).

The success of selection in improving plant characters depends mainly on presence of substantial genetic variability and nature of heritability and gene action. The genetic variability is the raw material of plant breeding programme on which selection acts to evolve superior genotypes. The phenotypic and genotypic coefficients of variation can be used for assessing and comparing the nature and magnitude of variability existing for different characters in the breeding materials. Heritability in broad sense quantifies the proportion of heritable genetic variance to total phenotypic variance. Estimates of heritability help in estimating expected progress through selection. The genetic advance in per cent of mean provides indication of expected selection response by taking into account the existing genetic variability and heritability of the character. 
Table.1 Analysis of variance of randomized block design (RBD) for 11 characters in wheat genotypes

\begin{tabular}{|c|c|c|c|c|}
\hline \multirow[t]{2}{*}{ Sr. no. } & \multirow[t]{2}{*}{ Characters } & \multicolumn{3}{|c|}{ Source of Variation } \\
\hline & & $\begin{array}{l}\text { Replication } \\
\text { d.f. } 2\end{array}$ & $\begin{array}{c}\text { Treatments } \\
19\end{array}$ & $\begin{array}{c}\text { Error } \\
38\end{array}$ \\
\hline 1 & Days to $50 \%$ Flowering & 1.71 & $5.79 *$ & 0.82 \\
\hline 2 & Tillers/ Plant & 0.71 & 1.88 & 0.36 \\
\hline 3 & Flag Leaf Area $(\mathrm{cm}) 2$ & 2.0 & $37.16^{*}$ & 0.89 \\
\hline 4 & Plants Height (cm) & 1.32 & $95.32 *$ & 0.26 \\
\hline 5 & Ear of Length/Plant (cm) & 1.40 & 1.95 & 0.16 \\
\hline 6 & Days to Maturity & 0.60 & $4.78 *$ & 1.41 \\
\hline 7 & Biological Yield/Plant (g) & 3.32 & $51.38 *$ & 1.37 \\
\hline 8 & Ear of Weight/ Plant (g & 0.05 & 1.99 & 0.35 \\
\hline 9 & No of Grains/Ear & 4.21 & 97.82 & 4.86 \\
\hline 10 & Harvest Index (\%) & 46.11 & $90.85 *$ & 13.79 \\
\hline 11 & Test Weight (g) & 0.68 & $46.71 *$ & 1.23 \\
\hline & Grain Yield/ Plant (g) & 1.76 & 5.13 & 0.47 \\
\hline
\end{tabular}


Table.2 Mean, range and other genetic parameters in wheat

\begin{tabular}{|c|c|c|c|c|c|c|c|c|c|}
\hline $\begin{array}{l}\text { Sr. } \\
\text { no }\end{array}$ & Characters & Mean & Range & GCV & PCV & ECV & $\begin{array}{l}h^{2} \text { Broad } \\
\text { sense } \%\end{array}$ & $\begin{array}{l}\text { Genetic } \\
\text { Advance }\end{array}$ & $\begin{array}{l}\text { Genetic } \\
\text { Advance as } \\
\% \text { of Mean }\end{array}$ \\
\hline 1 & Days to $50 \%$ Flowering & 68.43 & $65.66-71.0$ & 1.88 & 2.3 & 1.32 & 0.67 & 2.17 & 3.17 \\
\hline 2 & Tillers/Plant & 7.38 & $5.85-8.79$ & 9.63 & 12.62 & 8.16 & 0.58 & 1.12 & 15.14 \\
\hline 3 & Flag Leaf Area $(\mathrm{cm}) 2$ & 23.11 & $17.75-32.53$ & 15.04 & 15.59 & 4.09 & 0.93 & 6.91 & 29.9 \\
\hline 4 & Plants Height $(\mathrm{cm})$ & 68.82 & $62.68-84.40$ & 8.18 & 8.21 & 0.75 & 0.99 & 11.55 & 16.78 \\
\hline 5 & $\begin{array}{l}\text { Ear of Length/Plant } \\
(\mathrm{cm})\end{array}$ & 9.24 & $8.16-10.83$ & 8.35 & 9.43 & 4.37 & 0.79 & 1.41 & 15.25 \\
\hline 6 & Days to Maturity & 109.11 & $106.0-111.66$ & 0.97 & 1.46 & 1.09 & 0.44 & 1.45 & 1.33 \\
\hline 7 & $\begin{array}{l}\text { Biological Yield/Plant } \\
(\mathrm{g})\end{array}$ & 22.35 & $16.22-30.78$ & 18.26 & 19.0 & 5.25 & 0.92 & 8.08 & 36.16 \\
\hline 8 & Ear of Weight/Plant (g) & 6.92 & $5.20-8.59$ & 10.69 & 13.71 & 8.59 & 0.61 & 1.19 & 17.16 \\
\hline 9 & No of Grains/Ear & 41.86 & $33.41-56.6$ & 13.3 & 14.3 & 5.27 & 0.86 & 10.66 & 25.47 \\
\hline 10 & Harvest Index (\%) & 36.13 & $27.66-51.03$ & 14.03 & 17.39 & 10.28 & 0.65 & 8.42 & 23.31 \\
\hline 11 & Test Weight (g) & 23.60 & $18.26-32.24$ & 16.49 & 17.15 & 4.7 & 0.92 & 7.71 & 32.68 \\
\hline 12 & Grain Yield/Plant (g) & 7.96 & $5.13-9.86$ & 15.65 & 17.87 & 8.62 & 0.77 & 2.25 & 28.25 \\
\hline
\end{tabular}


Table.2.1 Mean value of various plant characters in wheat (Triticum aestivum L.)

\begin{tabular}{|c|c|c|c|c|c|c|c|c|c|c|c|c|c|}
\hline No & Character & $\begin{array}{r}\text { Days to } \\
50 \% \\
\text { Flowering }\end{array}$ & Tillers/Plant & $\begin{array}{l}\text { Flag } \\
\text { Leaf } \\
\text { Area } \\
(\mathrm{cm}) 2\end{array}$ & $\begin{array}{l}\text { Plants } \\
\text { Height } \\
\text { (cm) }\end{array}$ & $\begin{array}{r}\text { Ear of } \\
\text { Length/Plant } \\
(\mathrm{cm})\end{array}$ & $\begin{array}{r}\text { Days to } \\
\text { Maturity }\end{array}$ & $\begin{array}{r}\text { Biological } \\
\text { Yield/Plant } \\
(\mathrm{g})\end{array}$ & $\begin{array}{r}\text { Ear of } \\
\text { Weight/Plant } \\
(\mathrm{g})\end{array}$ & $\begin{array}{r}\text { No of } \\
\text { Grains/Ear }\end{array}$ & $\begin{array}{r}\text { Harvest } \\
\text { Index } \\
(\%)\end{array}$ & $\begin{array}{r}\text { Test } \\
\text { Weight } \\
(g)\end{array}$ & $\begin{array}{r}\text { Grain } \\
\text { Yield/Plant } \\
(\mathrm{g})\end{array}$ \\
\hline 1 & HD-2329 & 67.6667 & 6.8533 & 23.9300 & 67.0467 & 9.2333 & 109.6667 & 16.2333 & 6.1800 & 46.3333 & 42.5567 & 18.5600 & 6.9100 \\
\hline 2 & K-0307 & 67.0000 & 6.8867 & 26.0867 & 78.4733 & 10.5000 & 108.6667 & 30.7867 & 7.5367 & 43.6500 & 30.9567 & 26.1933 & 9.5067 \\
\hline 3 & HUW-234 & 65.6667 & 5.8533 & 17.7567 & 69.6233 & 8.1667 & 110.6666 & 19.5800 & 6.4400 & 40.4000 & 33.2400 & 21.1200 & 6.5100 \\
\hline 4 & HD-2733 & 70.3333 & 7.4067 & 21.6000 & 62.6867 & 8.4333 & 109.3333 & 22.7467 & 7.4067 & 33.4167 & 30.7800 & 22.4400 & 6.9133 \\
\hline 5 & DBW-14 & 67.3333 & 6.9333 & 19.0700 & 63.4433 & 8.7667 & 109.6666 & 18.1533 & 6.4600 & 39.0000 & 38.4100 & 23.6267 & 6.9333 \\
\hline 6 & HD-2643 & 68.3333 & 8.0067 & 24.5567 & 69.6367 & 8.5667 & 109.3334 & 23.8467 & 7.0133 & 38.8667 & 35.7400 & 28.5733 & 8.4633 \\
\hline 7 & KRL-213 & 70.3333 & 6.3333 & 24.3500 & 63.0567 & 9.1333 & 109.6667 & 25.7067 & 7.6833 & 56.6000 & 36.1367 & 19.4133 & 9.2900 \\
\hline 8 & ND-1014 & 68.6667 & 8.0667 & 24.0333 & 74.1767 & 8.6667 & 109.0000 & 22.5333 & 6.7100 & 36.0000 & 36.4667 & 23.2800 & 8.2300 \\
\hline 9 & UP-2338 & 68.0000 & 7.0667 & 23.3500 & 67.5000 & 9.4333 & 111.6666 & 19.3733 & 6.1200 & 50.1000 & 32.8467 & 19.5733 & 6.3633 \\
\hline 10 & K-9107 & 68.6667 & 7.7333 & 32.5333 & 84.4067 & 10.3000 & 109.6666 & 24.7000 & 7.9067 & 38.4000 & 35.9400 & 32.2400 & 8.8633 \\
\hline 11 & HP-2733 & 70.3333 & 8.6000 & 21.4167 & 67.5000 & 8.4000 & 109.0000 & 26.7733 & 6.7800 & 34.4667 & 31.9500 & 26.7200 & 8.5533 \\
\hline 12 & UP-262 & 68.6667 & 7.8000 & 20.0067 & 69.8100 & 10.8333 & 107.6666 & 23.1000 & 7.1633 & 37.6833 & 38.4300 & 27.0133 & 8.8200 \\
\hline 13 & MAHIK GOL & 67.6667 & 7.1333 & 29.6333 & 68.2333 & 10.8333 & 108.0000 & 22.4000 & 8.5933 & 39.8333 & 40.7800 & 27.8933 & 9.0967 \\
\hline 14 & NW-5054 & 68.0000 & 8.5867 & 20.3767 & 73.7400 & 9.0333 & 110.0000 & 28.9400 & 7.4933 & 41.4500 & 30.8233 & 25.7533 & 8.9100 \\
\hline 15 & HD-2307 & 67.3333 & 7.8000 & 23.3867 & 65.4067 & 9.5667 & 107.6666 & 19.4733 & 5.2033 & 41.5333 & 30.6700 & 19.2800 & 5.9633 \\
\hline 16 & RAJ-3765 & 67.6667 & 6.2667 & 21.3133 & 64.7667 & 8.5000 & 109.6667 & 18.5133 & 5.4900 & 39.1667 & 27.6633 & 18.9067 & 5.1333 \\
\hline 17 & NW-2036 & 67.3333 & 8.7667 & 19.9567 & 73.0167 & 9.1667 & 106.0000 & 20.3867 & 7.4700 & 47.1333 & 40.0367 & 22.2400 & 8.1700 \\
\hline 18 & HP-1761 & 70.3333 & 7.0667 & 24.6933 & 63.6267 & 8.9333 & 107.6667 & 16.2200 & 6.9000 & 49.3500 & 51.0300 & 18.2667 & 8.3000 \\
\hline 1 & PBW-343 & 71.0000 & 7.4667 & 23.7500 & 66.9700 & 9.5667 & 110.3334 & 27.7667 & 7.3467 & 43.7333 & 35.5200 & 25.2800 & 9.8633 \\
\hline 2 & PBW-502 & 68.3333 & 7.1333 & 20.5467 & 63.3800 & 8.9000 & 109.0000 & 19.8667 & 6.5933 & 40.0867 & 42.6433 & 25.7867 & 8.4500 \\
\hline
\end{tabular}


Table.3 Genotypic and penotyic correlation coefficient for 12 characters in wheat (Triticum aestivum L.)

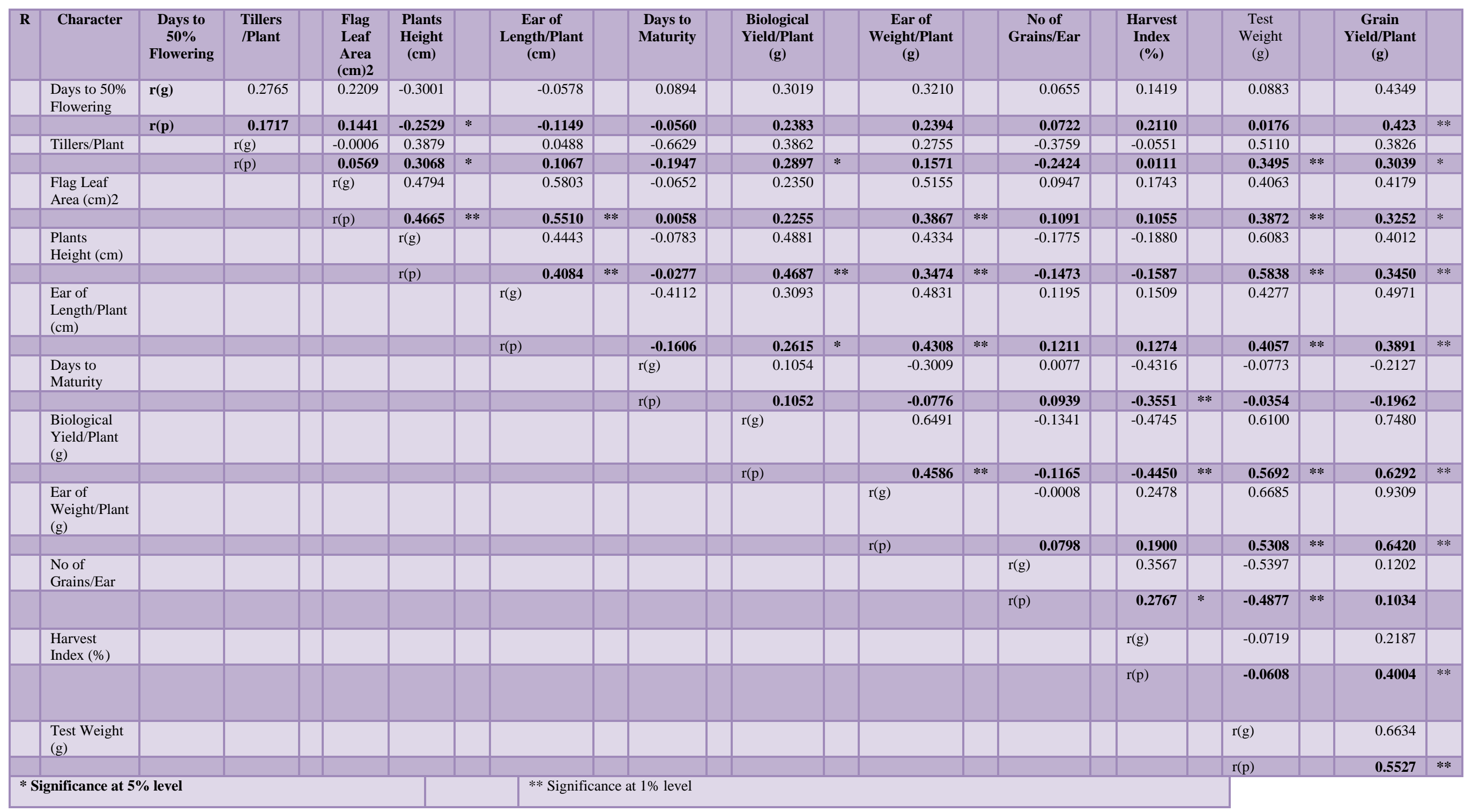


Table.4 Direct and indirect effect at genotypic level of different quantitative characters on yield in wheat (Triticum aestivum L.)

\begin{tabular}{|c|c|c|c|c|c|c|c|c|c|c|c|c|c|c|}
\hline No & Character & $\begin{array}{r}\text { Days to } \\
50 \% \\
\text { Flowering }\end{array}$ & $\begin{array}{l}\text { Tillers/ } \\
\text { Plant }\end{array}$ & $\begin{array}{r}\text { Flag Leaf } \\
\text { Area }(\mathrm{cm}) 2\end{array}$ & $\begin{array}{r}\text { Plants } \\
\text { Height }(\mathrm{cm})\end{array}$ & $\begin{array}{r}\begin{array}{r}\text { Ear of } \\
\text { Length/Plant } \\
(\mathbf{c m})\end{array}\end{array}$ & $\begin{array}{r}\text { Days to } \\
\text { Maturity }\end{array}$ & $\begin{array}{r}\text { Biological } \\
\text { Yield/Plant }(\mathrm{g})\end{array}$ & $\begin{array}{r}\text { Ear of } \\
\text { Weight/ } \\
\text { Plant (g) }\end{array}$ & $\begin{array}{r}\text { No of } \\
\text { Grains/Ear }\end{array}$ & $\begin{array}{r}\text { Harvest } \\
\text { Index }(\%)\end{array}$ & $\begin{array}{r}\text { Test } \\
\text { Weight } \\
\text { (g) }\end{array}$ & $\begin{array}{l}\text { Grain } \\
\text { Yield/ } \\
\text { Plant (g) }\end{array}$ & \\
\hline 1 & $\begin{array}{l}\text { Days to } 50 \% \\
\text { Flowering }\end{array}$ & 0.1154 & 0.0319 & 0.0255 & -0.0346 & -0.0067 & 0.0103 & 0.0349 & 0.0371 & 0.0076 & 0.0164 & 0.0102 & 0.4349 & $*$ \\
\hline 2 & Tillers/Plant & 0.0026 & 0.0093 & 0.0000 & 0.0036 & 0.0005 & -0.0062 & 0.0036 & 0.0026 & -0.0035 & -0.0005 & 0.0048 & 0.3826 & $*$ \\
\hline 3 & $\begin{array}{l}\text { Flag Leaf Area } \\
(\mathrm{cm}) 2\end{array}$ & -0.0261 & 0.0001 & -0.1182 & -0.0567 & -0.0686 & 0.0077 & -0.0278 & -0.0609 & -0.0112 & -0.0206 & -0.0480 & 0.4179 & $*$ \\
\hline 4 & Plants Height $(\mathrm{cm})$ & 0.0021 & -0.0028 & -0.0034 & -0.0071 & -0.0032 & 0.0006 & -0.0035 & -0.0031 & 0.0013 & 0.0013 & -0.0043 & 0.4012 & $*$ \\
\hline 5 & $\begin{array}{l}\text { Ear of Length/Plant } \\
(\mathrm{cm})\end{array}$ & -0.0032 & 0.0027 & 0.0319 & 0.0244 & 0.0550 & -0.0226 & 0.0170 & 0.0266 & 0.0066 & 0.0083 & 0.0235 & 0.4971 & $*$ \\
\hline 6 & Days to Maturity & -0.0007 & 0.0050 & 0.0005 & 0.0006 & 0.0031 & -0.0076 & -0.0008 & 0.0023 & -0.0001 & 0.0033 & 0.0006 & -0.2127 & \\
\hline 7 & $\begin{array}{l}\text { Biological } \\
\text { Yield/Plant (g) }\end{array}$ & 0.1617 & 0.2069 & 0.1259 & 0.2614 & 0.1657 & 0.0565 & 0.5356 & 0.3477 & -0.0718 & -0.2541 & 0.3267 & 0.7480 & $*$ \\
\hline 8 & $\begin{array}{l}\text { Ear of Weight/Plant } \\
\text { (g) }\end{array}$ & 0.0931 & 0.0800 & 0.1496 & 0.1257 & 0.1402 & -0.0873 & 0.1884 & 0.2902 & -0.0002 & 0.0719 & 0.1940 & 0.9309 & $*$ \\
\hline 9 & No of Grains/Ear & 0.0158 & -0.0908 & 0.0229 & -0.0429 & 0.0289 & 0.0019 & -0.0324 & -0.0002 & 0.2416 & 0.0862 & -0.1304 & 0.1202 & \\
\hline 10 & Harvest Index (\%) & 0.0467 & -0.0181 & 0.0573 & -0.0618 & 0.0496 & -0.1420 & -0.1561 & 0.0815 & 0.1173 & 0.3289 & -0.0236 & 0.2187 & \\
\hline 11 & $\begin{array}{l}\text { Test } 1000 \text { Grain } \\
\text { Weight/Plants (g) }\end{array}$ & 0.0274 & 0.1585 & 0.1260 & 0.1886 & 0.1326 & -0.0240 & 0.1892 & 0.2073 & -0.1673 & -0.0223 & 0.3101 & 0.6634 & * \\
\hline \multicolumn{15}{|c|}{ RESIDUAL EFFECT =SQRT(1- 1.0078) } \\
\hline
\end{tabular}


Variability with respect to the characters measured in terms of range, mean, PCV, GCV, heritability in broad sense and genetic advance in terms of per cent of mean have been presented in Table 2. The values for range among different genotypes varied highly for the characters like harvest index, no. of grain per ear, plant height, flag leaf area and biological yield per plant. These results are similar to those of Khan et al., (2011) and Maurya et al., (2014). The highest values for GCV and PCV were recorded for the character Biological yield per plant, test weight, grain yield per plant and harvest index. A close proximity between GCV and PCV values for almost all the characters revealed less influence of the environment on expression of the characters (Kumar et al., 2003). In the present experiment high heritability along with high genetic advance was obtained for plant height, flag leaf area, biological yield per plant, test weight, no. of grains per ear, ear length per plant and grain yield per plant. It can be concluded that since these characters are highly responsible for selection. Superior genotype can be evolved through selection on express of these characters. A heritability estimate alone is meaningless and along with genetic advance is more meaningful in predicting the ultimate effect of selection. It should be noted that non-additive genetic effects lowers the genetic gain while additive gene action is responsible for high genetic gain. The results are in conformity with the findings of Kumar (1985) and Kumar et al., (2014).

In the present investigation, simple correlation coefficients were computed among 12 characters (Table 3). Seed yield per plant was positively and significantly correlated at phenotypic level with days to $50 \%$ flowering (0.423), tillers per plant (0.3039), flag leaf area (0.3252), plant height $(0.3450)$, ear length (0.3891), biological yield (0.6292), ear weight $(0.6420)$ and test weight $(0.5527)$. It implies that by increasing the value of these component traits, seed yield can be drastically increased. These results are similar to those of Verma et al., 2019, Jee et al., 2019 and Garg et al., 2014. On the other hand, few quantitative traits were inter correlated with each other viz., Tillers per plant was positive significant correlation with plant height (0.3068), biological yield per plant (0.2897) and test weight (0.3495).Ear length showed highly significant and positive association with ear weight $(0.4308)$ and test weight (0.4057). Biological yield per plant showed highly significant positive correlation with ear weight (0.4586) and test weight (0.5692). Ear weight showed highly significant and positive association with test weight (0.5308). This suggests that selection would be quit efficient in improving yield and these nine yield components in wheat. Similar results have been reported by Kumar et al., (2014).

Path coefficient analysis is a tool to partition the observed correlation coefficient into direct and indirect effects of yield components on grain yield. Path analysis provides clearer picture of character associations for formulating efficient selection strategy. The results of path coefficient analysis carried out using simple correlation coefficients among 11 characters are given in Table 4.

Results revealed that biological yield per plant (0.5356) had positive and significant association with grain yield which exerted maximum direct effect on grain yield followed by harvest index (0.3289). Thus, biological yield per plant and harvest index emerged as major direct yield components. These traits could be considered as important traits for selection in a breeding program for higher grain yield of the bread wheat. These results are similar to those of Singh et al., 2012; Phougat et al., 2017. The highest positive indirect effect on grain yield was exerted by Days to $50 \%$ flowering (0.0319) via tillers per plant followed by days to $50 \%$ flowering (0.0255) via flag leaf area. These characters emerged as most important indirect yield contributing characters because they showed substantial positive indirect effect towards grain yield. The remaining estimates of indirect effects in this analysis were very low indicating their importance indirect contribution towards grain yield. 


\section{References}

Dewey SR, Lu KH. Correlation and path coefficient analysis of crested wheat gross seed production. Agron. J. 1959; 51: 515518.

Garg P, Saharan RP, Chawla V, Gupta M. Correlation and path analysis fir yield and its components in wheat (Triticum aestivum $\mathrm{L}$ em. Thell.) Under normal and drought conditions. Annals of Biology. 2014; 30(1): 71-76.

Grafius JE. Does overdominance exist for yield in corn. Agron. J. 1960; 52: 361.

JeeChaman, VN Pathak, SP Verma, OP Verma and OP Singh. Association studies for grain yield and its contributing components in diverse genotypes of wheat (Triticum aestivumL. em. Thell). J. of Pharmacognosy and Phytochemistry, 2019; 8(3): 1177-1180.

Khan MAU, Abbas TM, Zaheer SJ, Khan AA, Malik M and Asghar S. 2011.Study of genetic variability and correlation among various traits of F5 wheat (Triticum aestivum L.) populations. International Research Journal of Agricultural Science and Soil Science 1(8): 344-348.

Kumar Salendra, V.K. Dwivedi and N.K. Tyagi. Genetic variability in some metric traits and its contribution to yield in wheat (Triticum aestivum L.). Progressive Agriculture, 2003; 3 (1/2): 152-153.

Kumar, J. (1985) Stability and combining ability study for some metric traits releated to productivity in spring wheat (Triticum aestivum L.) Unpublished thesis, C. S. A. U. and A. T. Kanpur
Kumar, Y., Lamba, R. A. S., Balbir Singh and Vinod Kumar. Genetic variability, correlation and path analysis in wheat varieties under late sown condition. Annals of Agri Bio Research. 2014; 19(4): 724-727.

Maurya M., Chaurasia A. K., Kumar A., Maurya C. L., Bara B. M., kumar M., Rai P.K. Genetic Variability for Seed Yield and Its Component Characters in Wheat (Triticum aestivum L.) Under Allahabad Agro-Climatic Conditions. Int. J. Rec. Dev. Engg. \& Tech.2014; 2 (4): 124-126.

PhougatDivya; Panwar, I. S., Saharan, R. P., Vikram Singh and AnuradhaGodara. Genetic diversity and association studies for yield attributing traits in bread wheat [Triticum aestivum (L.) em. Thell]. Rec. on Crops. 2017; 18 (1): 139-144.

Searle, S.R. 1961. Phenotypic, genotypic and environmental correlations. Biometrics. 17: 474-480.

Singh, A. K., Singh, S. B., Singh, A. P., Sharma, A. K. Genetic variability, character association and path analysis for seed yield and its component characters in wheat (Triticum aestivum L.) under rainfed environment. Indian Journal of Agricultural Research. 2012; 46(1): 4853.

Verma SP, VN Pathak, OP Verma. Interrelationship between Yield and its Contributing Traits in Wheat (Triticum aestivum L). Int. J Curr. Microbiol. App. Sci. 2019; 8(2): 3209-3215.

Wright, S. (1921). J. Sci. Fd. Agri. 12: 59.

\section{How to cite this article:}

Suryabhushan Kumar, Brijesh Singh, S.P. Verma, V.N. Pathak, Chaman Jee and Singh, J.P. 2019. Studies on Genetic Variability, Heritability, Genetic Advance, Correlation and Path Analysis for Grain Yield and Its Contributing Traits in Indigenous Wheat (Triticum aestivum L.). Int.J.Curr.Microbiol.App.Sci. 8(08): 1408-1416. doi: https://doi.org/10.20546/ijcmas.2019.808.164 